\title{
PENERAPAN MODEL PROBLEM BASED LEARNING UNTUK MENINGKATKAN AKTIVITAS DAN HASIL BELAJAR SISWA SMP
}

\author{
Sarah Marta Ningsih ${ }^{1 *}$,Sri Irawati ${ }^{1}$, Irdam Idrus ${ }^{1}$ \\ ${ }^{1}$ Program Studi Pendidikan Biologi, Fakultas Keguruan dan Ilmu Pendidikan, Universitas Bengkulu \\ email : Sarahmarta.ningsih@yahoo.co.id
}

\begin{abstract}
Abstrak
Penelitian ini bertujuan untuk mendeskripsikan aktivitas mengajar guru, aktivitas belajar siswa dan meningkatkan hasil belajar siswa dengan menerapkan model Problem Based Learning pada materi Pencemaran Lingkungan di Kelas $\mathrm{VII}_{8}$ SMPN 4 Kota Bengkulu. Jenis penelitian ini adalah Penelitian Tindakan Kelas dengan metode deskriptif. Penelitian ini terdiri dari dua siklus, masing-masing siklus terdiri dari empat tahap yaitu perencanaan, pelaksanaan, pengamatan dan refleksi. Subjek penelitian ini adalah seluruh siswa kelas VII 8 SMPN 4 Kota Bengkulu tahun ajaran 2016/2017, sedangkan peneliti berperan sebagai guru. Variabel penelitian ini adalah model Problem Based Learning, aktivitas mengajar guru, aktivitas belajar siswa dan hasil belajar siswa. Teknik pengumpulan data dalam penelitian ini yaitu observasi dan tes. Instrumen penelitian yang digunakan adalah lembar observasi dan lembar tes. Hasil analisis data aktivitas guru siklus I diperoleh skor rata-rata yaitu 26 (Baik), pada siklus II skor aktivitas guru menjadi 28 (Baik). Hasil analisis data aktivitas siswa pada siklus I diperoleh skor rata-rata 26 (Baik), dan pada siklus II skor aktivitas siswa menjadi 29 (Baik). Selanjutnya data hasil belajar siswa pada siklus I dianalisis berdasarkan kriteria ketuntasan belajar klaksikal pada hasil belajar kompetensi pengetahuan siklus I mendapatkan persentase $80,6 \%$, siklus II menjadi 88,9\%, pada hasil belajar kompetensi sikap siklus I mendapatkan persentase 83,3\%, siklus II menjadi $100 \%$, pada hasil belajar kompetensi keterampilan siklus I dan siklus II mendapatkan persentase $100 \%$. Disimpulkan bahwa model problem based learning dapat meningkatkan aktivitas dan hasil belajar siswa kelas VII 8 SMPN 4 Kota Bengkulu.
\end{abstract}

Kata Kunci : Problem Based Learning, Aktivitas, Hasil Belajar

\begin{abstract}
This study aims to describe teacher teaching activities, student learning activities and improve student learning outcomes by applying Problem Based Learning model on Environmental Pollution material in Class $\mathrm{VII}_{8}$ SMPN 4 Kota Bengkulu. This research is Classroom Action Research with descriptive method. This study consists of two cycles, each cycle consists of four stages of planning, implementation, observation and reflection. The subjects of this study were all students of grade $\mathrm{VII}_{8}$ SMPN 4 Kota Bengkulu academic year 2016/2017, while researchers role as teachers. The variables of this research are Problem Based Learning model, teacher teaching activity, student learning activity and student learning result. Technique of collecting data in this research that is observation and test. The research instrument used was observation sheet and test sheet. The results of data analysis of teacher activity cycle I obtained an average score of 26 (Good), on the second cycle of teacher activity scores to 28 (Good). The result of data analysis of student activity in cycle I obtained average score 26 (Good), and in cycles II score of student activity to 29 (Good). Furthermore the data of student learning outcomes in cycle I analyzed based on climax learning completeness criteria on the learning outcomes knowledge competence cycle I get the percentage of $80.6 \%$, cycle II to $88.9 \%$. on the result of competence affective learning cycle I get the percentage $83.3 \%$, cycle II to $100 \%$, on the result of competence learning skill cycle I and cycles II get $100 \%$ percentage. It was concluded that the problem-based learning model can improve the activity and learning outcomes of students of class $\mathrm{VII}_{8}$ SMPN 4 Kota Bengkulu.
\end{abstract}

Keywords : Problem Based Learning, Activity, Learning Outcomes 


\section{PENDAHULUAN}

Pendidikan adalah usaha sadar dan terencana untuk mewujudkan suasana belajar dan proses pembelajaran agar peserta didik secara aktif mengembangkan potensi dirinya untuk memiliki kekuatan spiritual keagamaan, pengendalian diri, kepribadian, kecerdasan, akhlak mulia, serta keterampilan yang diperlukan dirinya, masyarakat, bangsa dan negara. Undangundang nomor 20 tahun 2003 pasal 3 menyebutkan, bahwa pendidikan nasional berfungsi mengembangkan kemampuan dan membentuk watak serta peradaban bangsa yang bermartabat dalam rangka mencerdaskan kehidupan bangsa.

Berdasarkan pengamatan awal dan diskusi yang dilakukan peneliti dengan guru mata pelajaran biologi di kelas $\mathrm{VII}_{8}$ SMPN 4 Kota Bengkulu pada tanggal 30 Januari 2017 terhadap pembelajaran dikelas, masalah pembelajaran pada siswa dikelas adalah aktivitas dan hasil belajar siswa masih kurang. Penyebab masalah tersebut dari aspek pembelajaran oleh guru adalah pada saat proses pembelajaran kegiatannya lebih banyak melibatkan guru sehingga siswa dalam belajar mengajar lebih cenderung pasif, guru masih kurang melibatkan siswa untuk memecahkan masalah yang ada dikehidupan nyata mereka dan mengaitkan masalah tersebut dengan materi pembelajaran, model pembelajaran yang digunakan oleh guru belum optimal.

Permasalahan yang terjadi pada siswa adalah siswa kurang aktif dalam proses belajar mengajar (KBM) yang sedang berlangsung seperti bertanya dan menyatakan pendapat, sehingga mereka tidak terbiasa mengembangkan kemampuan berpikirnya dan akhirnya mereka hanya menerima informasi saja, siswa masih menjadikan guru satusatunya sumber belajar padahal buku untuk menunjang pembelajaran sudah diberikan, siswa kurang memahami materi yang disampaikan sehingga tidak bisa memecahkan masalah tersebut, dari permasalahan proses pembelajaran tersebut berpengaruh terhadap hasil belajar siswa.

Berdasarkan Kriteria Ketuntasan Minimal (KKM) untuk mata pelajaran IPA Biologi di SMPN 4 Kota Bengkulu yaitu $\geq 75$ dengan ketuntasan belajar klasikal $\geq 85 \%$, tetapi masih banyak siswa yang belum mencapai angka ketuntasan tersebut. Berdasarkan data yang diperoleh dari guru IPA - Biologi SMPN 4 Kota Bengkulu dengan melihat hasil ulangan mid semester yang dilakukan pada bulan Desember 2016 di SMPN 4 Kota Bengkulu khususnya di kelas $\mathrm{VII}_{8}$ yang merupakan subjek penelitian peneliti. Diperoleh hasil ulangan siswa dari 36 siswa hanya 14 siswa yang mendapatkan nilai $\geq 75$ dan 22 orang siswa mendapatkan nilai dibawah 75. Hal ini berarti hanya $38,88 \%$ siswa kelas $\mathrm{VII}_{8}$ yang tuntas belajar biologi secara klasikal. Kondisi ini menunjukkan bahwa diperlukannya suatu usaha perbaikan dalam model pembelajaran biologi yang dapat merangsang siswa untuk belajar secara aktif dalam proses belajar mengajar, sehingga diharapkan nilai hasil belajar siswa lebih meningkat pada tiap-tiap siswa demi tercapainya kurikulum yang sudah ditetapkan disekolah.

Penerapan model Problem Based Learning pada materi pencemaran lingkungan dengan kompetensi dasar yang harus dicapai oleh siswa yaitu KD 3.9 Mendiskripsikan pencemaran dan dampaknya bagi makhluk hidup dinilai tepat karena materi tersebut mendorong siswa untuk melakukan pemecahan masalah terhadap lingkungan dimana siswa akan belajar di mulai dari lingkungan sekitar siswa dan dikaitkan pada materi disekolah. Hal ini sejalan 
dengan penelitian yang dilakukan oleh Harahap dan Prastowo (2014) bahwa model Problem Based Learning baik digunakan pada materi pencemaran lingkungan dan upaya mengatasinya. Menerapkan model tersebut pada materi pencemaran lingkungan dan upaya mengatasinya, diharapkan diantara siswa terjalin komunikasi yang baik. Dimana siswa saling berbagi ide dan pendapat, saling mendiskusikan masalah-masalah yang ada pada lingkungan sehingga mereka lebih mudah menemukan dan mengemukakan ide atau solusi dalam penyelesaian masalah yang ada pada lingkungan. Selain itu, siswa juga dapat berperan aktif dalam proses belajar mengajar, serta siswa mampu terbiasa berpikir secara kritis. Penerapan model Problem Based Learning pada materi pencemaran lingkungan ini diharapkan dapat meningkatkan aktivitas belajar siswa di SMPN 4 Kota Bengkulu Khususnya Kelas $\mathrm{VII}_{8}$. Dengan adanya aktivitas yang tinggi diharapkan dapat meningkatkan hasil belajar siswa.

\section{METODE}

Jenis penelitian ini adalah penelitian tindakan kelas (Classroom Action Research). Penelitian ini menggunakan metode deskriptif. Menurut Sukardi (2013) metode deskriptif adalah metode penelitian yang ditujukan untuk mendeskripsikan atau menggambarkan secara sistematis fakta dan karakteristik objek atau subjek yang diteliti dengan tepat melalui pengumpulan data untuk mengetes pertanyaan penelitian yang berkaitan dengan keadaan sekarang. Dalam penelitian ini metode deskriptif digunakan untuk memperoleh deskripsi aktivitas serta hasil belajar IPA - Biologi siswa dengan menerapkan model Problem Based Learning di SMPN 4 Kota Bengkulu. Subjek penelitian tindakan kelas ini adalah guru dan seluruh siswa kelas $\mathrm{VII}_{8}$ SMPN 4
Kota Bengkulu tahun ajaran 2016/2017 yang berjumlah 36 orang. Penentuan subyek tersebut secara Convenience Sampling yaitu sampel berdasarkan kemudahan atau ketersediaan individu yang ada dalam suatu kelompok untuk menjadi subjek penelitian (Zuriah, 2009). Teknik pengumpulan data yang digunakan dalam penelitian ini yaitu observasi dan tes.

Instrumen yang digunakan dalam penelitian ini yaitu lembar observasi dan lembar tes. Dalam penelitian ini lembar observasi yang digunakan yaitu lembar observasi aktivitas mengajar guru dan lembar observasi aktivitas belajar siswa pada proses pembelajaran biologi materi pencemaran lingkungan dengan menerapkan model Problem Based Learning. Instrumen untuk mengumpulkan data ketuntasan hasil belajar digunakan lembar tes dalam bentuk tes pilihan ganda. Menurut Dirman dan Juarsih (2014) Tes pilihan ganda terdiri atas pembawa pokok persoalan dan pilihan jawaban. Penelitian tindakan kelas ini dilakukan dengan dua siklus yang mencakup empat langkah sebagai berikut: (1) Perencanaan, (2) Pelaksanaan, (3) Pengamatan, (4) Refleksi (Arikunto dkk, 2015).

Data hasil observasi aktivitas guru akan dianalisis dengan menentukan nilai rata-rata yang diperoleh dari 2 orang pengamat. Penentuan kriteria rarata hasil pengamatan dilakukan dengan menetukan kisaran skor kriteria baik, cukup dan kurang.

$$
\text { Menurut arikunto (2010) }
$$
menghitung kisaran skor menggunakan rumus:

1) Rata-rata skor $=\frac{\text { Jumlah skor }}{\text { Jumlah observer }}$

2) Skor tertinggi = Jumlah aspek yang diamati $\times$ skor tertinggi setiap aspek

3) Skor terendah = jumlah aspek yang diamati $\times$ skor terendah setiap aspek 
4) Selisih skor $=$ Skor tertinggi - Skor terendah

5) Kisaran nilai untuk tiap kriteria pengamatan $=\frac{\text { Selisih } \text { skor }}{\text { Jumlah } \text { kriteria penilaian }}$

Kriteria rerata skor aktivitas guru dan siswa dapat dilihat pada Tabel 1.

Tabel 1. Kriteria Penilaian Lembar Observasi Aktivitas Guru dan Siswa

\begin{tabular}{lll}
\hline No & $\begin{array}{l}\text { Interval } \\
\text { Penilaian }\end{array}$ & $\begin{array}{l}\text { Kriteria } \\
\text { Penilaian }\end{array}$ \\
\hline 1 & $10-16$ & Kurang (1) \\
2 & $17-23$ & Cukup (2) \\
3 & $24-30$ & Baik (3) \\
\hline
\end{tabular}

Untuk menganalisis data hasil belajar kognitif siswa dapat dihitung dengan menggunakan rumus Arikunto (2010) berikut :

1) Rerata dapat dihitung dengan menggunakan rumus sebagai berikut :

$$
X=\sum X
$$

Keterangan :

$X$ : Nilai rata-rata siswa

$\sum x$ : Jumlah nilai siswa

$\sum N$ : Jumlah siswa

2) Persentase Ketuntasan Belajar Klasikal dapat dihitung dengan menggunakan rumus :

$$
K B=\frac{N}{S} \times 100 \%
$$

Keterangan :

KB : Ketuntasan belajar klasikal

$N$ : Jumlah siswa yang memperoleh nilai $\geq 75$

$S$ : Jumlah siswa

Analisis data hasil belajar afektif dihitung dengan menggunakan rumus (Zubaidah, 2014) :

$$
\text { Skor akhir }=\frac{\begin{array}{c}
\text { skor yang } \\
\text { diperoleh }
\end{array}}{\text { skor maksimal }} \times 4
$$

Data hasil belajar psikomotorik dihitung menggunakan rumus sebagai berikut (panduan penilaian untuk SMP tahun 2015).

$$
\begin{aligned}
& \text { jumlah skor }
\end{aligned}
$$

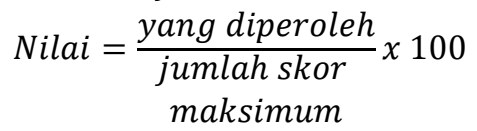

\section{HASIL DAN PEMBAHASAN}

Berdasarkan hasil penelitian yang telah dilaksanakan di kelas $\mathrm{VII}_{8}$ SMPN 4 Kota Bengkulu dengan menerapkan Model Problem Based Learning sebanyak 2 siklus pembelajaran yang berfokus pada aktivitas mengajar guru, aktivitas belajar siswa dan hasil belajar siswa pada materi Pencemaran Lingkungan, diperoleh hasil sebagai berikut

Tabel 2. Data Hasil Aktivitas Guru dan Siswa

\begin{tabular}{ccccc}
\hline Aktivitas & \multicolumn{2}{c}{ Siklus I } & \multicolumn{2}{c}{ Siklus II } \\
\cline { 2 - 5 } & Rerata & Kriteria & Rerata & Kriteria \\
\hline Aktivitas Guru & 26 & Baik & 28 & Baik \\
Aktivitas Siswa & 26 & Baik & 29 & Baik \\
\hline
\end{tabular}

\section{Aktivitas Guru Dan Siswa Dari Siklus I Ke Siklus II}

Kegiatan aktivitas mengajar guru dan aktivitas belajar siswa terdapat di dalam setiap sintaks model Problem Based Learning berikut :

\section{1) Orientasi siswa pada masalah}

Pada aspek ini aktivitas guru dan aktivitas siswa sudah berjalan dengan baik, hal ini dapat dilihat dari perolehan skor yang diberikan oleh kedua pengamat 
pada siklus I dan siklus II yaitu dalam kriteria baik.

Aspek yang kedua guru memotivasi siswa untuk terlibat dalam pemecahan masalah yang dipilihnya dengan cara menanyakan pemahaman siswa terkait artikel pada siklus I dan gambar pada siklus II yang sudah dibagikan. Pada aspek ini aktivitas guru dan aktivitas siswa sudah berjalan dengan baik, hal ini dapat dilihat dari perolehan skor yang diberikan kedua pengamat pada siklus I dan siklus II yaitu dalam kriteria baik.

Pada aspek yang ketiga yaitu guru menjelaskan tujuan pembelajaran. Pada aspek ini aktivitas guru dan aktivitas siswa dinilai oleh kedua observer termasuk kedalam katagori cukup pada siklus I, sedangkan pada aktivitas siswa kedua observer menilai cukup karena siswa memperhatikan tetapi tidak mencatat tujan pembelajaran yang disampaikan oleh guru. Tujuan pembelajaran ini menjadi harapan siswa setelah pembelajaran selesai, sehingga saat pembelajaran berlangsung siswa dapat mengembangkan kemampuan berfikirnya dalam memecahkan suatu permasalahan yang diberikan guru melalui LDS pada siklus I dan LKS pada siklus II. Hal ini sesuai dengan pernyataan Khalifah (2013), bahwasanya tujuan pembelajaran merupakan harapan siswa sebagai hasil belajar telah dilaksanakan. Setelah dilakukan refleksi, terjadi peningkatan aktivitas guru dan aktivitas siswa pada siklus II yaitu guru menyiapkan spidol sebelum berlangsungnya proses pembelajaran dan guru menuliskan tujuan pembelajaran dipapan tulis kemudian menjelaskannya, sedangkan aktivitas siswa yaitu siswa memperhatikan dan mencatat tujuan pembelajaran yang disampaikan oleh guru. Pada kegiatan aktivitas guru dan aktivitas siswa pada siklus II tersebut sudah berjalan dengan baik. Hal ini dapat dilihat dari perolehan skor yang diberikan kedua pengamat yaitu dalam kriteria baik.

\section{2) Mengorganisasikan siswa}

Pada aspek yang pertama di tahap ini yaitu guru membimbing siswa dalam pembagian kelompok, hal ini bertujuan agar siswa dapat mengembangkan kemampuan bersosialisasi dengan temantemannya. Sehingga siswa dapat mengembangkan pemikirannya dalam memecahkan suatu masalah, kesulitan belajar siswa secara individu dapat diatasi melalui kerja kelompok. Pada aspek ini kedua observer menilai cukup karena guru hanya meminta siswa membagi kelompok sendiri secara heterogen. Rusman (2014) salah satu peranan guru dalam belajar yaitu guru berperan sebagai organisator dimana guru mengatur proses jalannya kegiatan pembelajaran dari awal sampai akhir agar kegiatan belajar dapat berjalan dengan baik dan lancar. Setelah dilakukan refleksi, aktivitas guru dan aktivitas siswa pada siklus II sudah berjalan dengan baik, dapat dilihat dari hasil yang diperoleh dari kedua observer yaitu dalam kriteria baik (B).

Pada aspek yang kedua guru memberikan LDS pada siklus I dan LKS pada siklus II kepada siswa dan guru menjelaskan langkah kerja LDS pada siklus I dan LKS pada siklus II. Pada kedua kegiatan tersebut aktivitas guru dan aktivitas siswa sudah berjalan dengan baik, dapat dilihat dari hasil yang diperoleh dari kedua observer pada siklus I dan siklus II yaitu dalam kriteria baik (B).

\section{3) Membimbing pengalaman individual/kelompok}

Pada aspek guru membimbing kelompok siswa untuk mengumpulkan informasi yang sesuai, melaksanakan diskusi untuk mendapatkan penjelasan dan pemecahan masalah pada LDS. Pada tahap ini siswa dituntut aktif dalam mencari data atau informasi bersama 
kelompoknya dalam proses pemecahan masalah. Hal ini selaras dengan pendapat Sani (2014) bahwa pembelajaran dengan model Problem Based Learning menuntut siswa untuk aktif melakukan penyelidikan dalam menyelesaikan permasalahan dan guru berperan sebagai fasilitator atau pembimbing. Pada kegiatan tersebut aktivitas guru dan aktivitas siswa pada siklus I dan siklus II sudah berjalan dengan baik, dapat dilihat dari hasil yang diperoleh dari kedua observer pada siklus I dan siklus II yaitu dalam kriteria baik (B).

\section{4) Mengembangkan dan menyajikan hasil karya}

Pada siklus I aktivitas guru dan aktivitas siswa sudah dikategorikan baik oleh kedua observer, hal ini terlihat dari skor yang diberikan oleh kedua observer dengan kriteria baik (B).

Pada aspek kedua guru membimbing setiap kelompok siswa untuk mempresentasikan laporan hasil diskusi didepan kelas. Pada aspek ini aktivitas guru pada siklus I dan siklus II sudah dikategorikan dalam kriteria baik oleh kedua observer, hal ini terlihat dari skor yang diberikan oleh kedua observer dengan kriteria baik. Pada tahap aktivitas siswa ini masing-masing kelompok siswa mempresentasikan hasil diskusi kelompoknya dan kelompok lain bisa menanggapi dan memberikan beberapa pertanyaan yang berkaitan dengan presentasi. Disini akan terlihat bagaimana keterampilan berfikir siswa dalam memecahkan masalah dunia nyata terkait permasalahan yang ada di LDS pada siklus I dan LKS pada siklus II, selain itu keterampilan berkomunikasi juga akan terlihat pada saat siswa mempresentasikan hasil pemecahan masalahnya didepan kelas. Hal ini sesuai dengan pendapat Suardani (2014) yang menyatakan bahwa model Problem Based Learning memungkinkan siswa untuk terlibat dalam mempelajari beberapa keterampilan seperti menyelesaikan permasalahan dunia nyata, keterampilan mengali informasi, keterampilan belajar berkomunikasi. Pada aspek ini aktivitas siswa siklus I dan siklus II sudah berjalan dengan baik, dapat dilihat dari hasil yang diperoleh dari kedua observer yaitu dalam kriteria baik.

\section{5) Menganalisis dan mengevaluasi proses pemecahan masalah}

Pada aspek pertama guru membantu siswa untuk melakukan refleksi terhadap materi yang telah diajarkan, Pada siklus I aktivitas guru dan aktivitas siswa dikategorikan kurang (K) oleh kedua observer karena guru hanya membimbing 2 kelompok siswa untuk melakukan refleksi terhadap materi yang telah diajarkan. Selain itu karena keterbatasan waktu yang menyebabkan aktivitas tersebut tidak berjalan dengan efektif. Kelemahan Model Problem Based Learning menurut Gunantara (2014) bahwasanya Model Problem Based Learning ini membutuhkan waktu yang tidak sedikit dalam kegiatan pembelajaran, sehingga dibutuhkan kemampuan guru dalam mengelolah waktu agar kegiatan pembelajaran dapat berjalan dengan baik dan lancar. Setelah dilakukan refleksi terhadap aktivitas guru dan aktivitas siswa pada siklus II terjadi peningkatan dimana kedua observer menilai aktivitas guru dan aktivitas siswa tersebut dalam kategori cukup (C), karena guru belum maksimal dalam membimbing kelompok siswa dimana hanya 4 kelompok siswa yang dibimbing guru untuk melakukan refleksi terhadap materi yang telah diajarkan.

Aspek selanjutnya guru melakukan evaluasi di akhir pembelajaran. Hal ini sesuai dengan pendapat Wijaya dkk (2015) bahwa evaluasi pembelajaran adalah sebagai sebuah proses 
menentukan hasil yang telah dicapai dari beberapa kegiatan yang direncanakan untuk mendukung tercapainya tujuan pembelajaran. Pada kegiatan tersebut aktivitas guru dan aktivitas siswa pada siklus I dan siklus II sudah berjalan dengan baik, dapat dilihat dari hasil yang diperoleh dari kedua observer yaitu dalam kriteria baik (B).

Berdasarkan hasil pengamatan proses pembelajaran dengan menerapkan model Problem Based Learning dapat meningkatkan aktivitas mengajar guru pada siklus I dengan skor 26 dan meningkat pada siklus II dengan skor 28 . Aktivitas belajar siswa pada siklus I dengan skor 26 meningkat menjadi 29 pada siklus II. Rata-rata skor aktivitas guru dan aktivitas siswa pada siklus I dan Siklus II dapat dilihat pada Gambar 1.

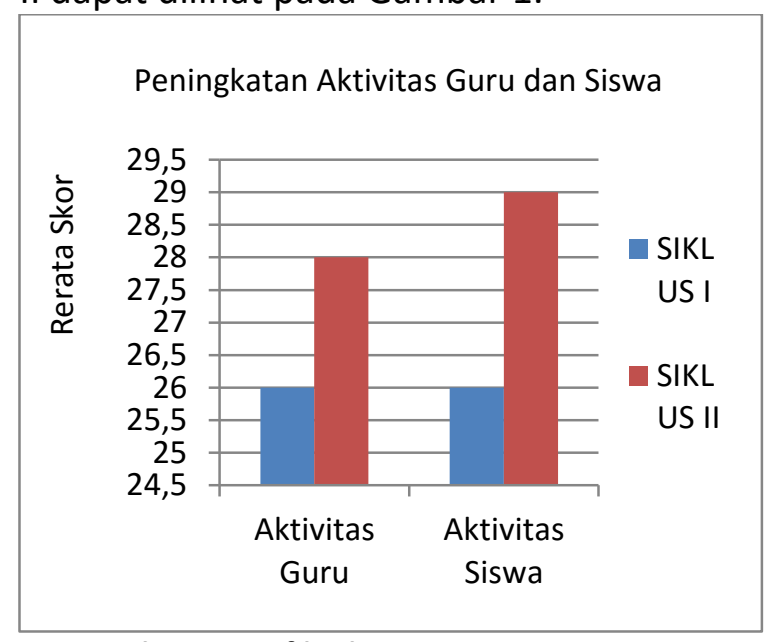

Gambar 1. Grafik Aktivitas Guru Dan Siswa

Tabel 3. Hasil Belajar Siswa

\begin{tabular}{|c|c|c|c|c|c|c|}
\hline \multirow[t]{2}{*}{ Siklus } & \multicolumn{2}{|c|}{ Pengetahuan } & \multicolumn{2}{|c|}{ Sikap } & \multicolumn{2}{|c|}{ Keterampilan } \\
\hline & $\begin{array}{l}\text { Presentase } \\
\text { Ketuntasan } \\
\text { Klaksikal }\end{array}$ & Kriteria & $\begin{array}{c}\text { Presentase } \\
\text { Ketuntasan } \\
\text { Klaksikal }\end{array}$ & Kriteria & $\begin{array}{l}\text { Presentase } \\
\text { Ketuntasan } \\
\text { Klaksikal }\end{array}$ & Kriteria \\
\hline I & $80,6 \%$ & $\begin{array}{l}\text { Tidak } \\
\text { Tuntas }\end{array}$ & $83,3 \%$ & Baik & $100 \%$ & Tuntas \\
\hline II & $88,9 \%$ & Tuntas & $100 \%$ & Sangat Baik & $100 \%$ & Tuntas \\
\hline
\end{tabular}

Hasil Belajar Siswa dari Siklus I Ke Siklus II Berdasarkan penelitian tindakan kelas (PTK) yang telah dilakukan selama 2 siklus pembelajaran ini tidak hanya terdapat peningkatan aktivitas guru dan aktivitas siswa saja, melainkan juga terdapat peningkatan pada hasil belajar siswa. Peningkatan proses pembelajaran yang terjadi sejalan dengan peningkatan hasil belajar yang dicapai oleh siswa. Menurut Green dalam Idrus (2009) Penilaian hasil belajar idealnya dapat mengungkap semua aspek domain

\section{Hasil Belajar Kompetensi Pengetahuan}

Pengukuran atau penilaian kompetensi pengetahuan menurut
Kosasih (2014) bertujuan untuk mengukur kemampuan siswa yang bersifat kognitif. Berdasarkan analisis data hasil belajar penerapan model Problem Based Learning pada materi Pencemaran Lingkungan kelas $\mathrm{VII}_{8}$ SMPN 4 Kota Bengkulu telah terjadi peningkatan pada kompetensi pengetahuan dari siklus I ke siklus II dengan ketuntasan klasikalnya yaitu sebesar $85 \%$. Pada siklus I diketahui bahwa jumlah persentase belajar klasikal siswa yang tuntas sebesar $80,6 \%$. Ini berarti siswa yang memperoleh nilai $\geq 75$ berjumlah sebanyak 29 orang siswa dari 36 orang siswa yang ada. Sedangkan pada siklus II diketahui bahwa siswa yang tuntas klasikal sebesar $88,9 \%$. Ini berarti siswa yang memperoleh nilai $\geq 75$ 
sebanyak 32 orang siswa dari 36 orang siswa yang ada. Dari data tersebut berarti terjadi peningkatan hasil belajar kompetensi pengetahuan dari siklus I ke siklus II sebesar 8,3 point.

\section{Hasil Belajar Kompetensi Sikap (Afektif)}

Berdasarkan analisis data hasil

belajar penerapan model Problem Based Learning pada materi Pencemaran Lingkungan kelas $\mathrm{VII}_{8}$ SMPN 4 Kota Bengkulu terjadi peningkatan pada kompetensi sikap dari siklus I ke siklus II dengan ketuntasan klasikalnya yaitu dari sebesar $85 \%$ dengan aspek yang diamati yaitu sikap disiplin, sikap jujur dan sikap bekerjasama. Dari hasil yang didapatkan persentase ketuntasan klasikalnya adalah $83,3 \%$, artinya pada siklus I ini siswa belum mencapai ketuntasan klasikal yang telah ditetapkan oleh sekolah yaitu sebesar $85 \%$.

Pada siklus II setelah dilakukan refleksi, ketuntasan klasikal kompetensi sikap sudah mencapai $100 \%$ yang artinya pada siklus II ini kompetensi sikap siswa sudah dikatakan tuntas karena telah mencapai ketuntasan klasikal yang telah ditetapkan di SMPN 4 Kota Bengkulu sebesar $85 \%$. Dari data hasil penilaian ranah sikap terlihat adanya peningkatan sebesar 16,7 point dari siklus I ke siklus II. Peningkatan persentase jumlah ketuntasan $\geq 85 \%$ ini menunjukkan bahwa model Problem Based Learning dapat meningkatkan hasil belajar kompetensi sikap. Selaras dengan yang dikemukakan oleh Al-Tabany (2014) bahwa dengan menggunakan model Problem Based Learning dapat menjadikan siswa lebih mandiri dan dewasa, mampu memberi aspirasi dan menerima pendapat orang lain, mananamkan sikap sosial yang positif diantara siswa. dimana telah dilakukan pada proses pembelajaran bahwa siswa dilatih untuk memiliki sikap disiplin, sikap jujur dan sikap bekerjasama dalam kelompoknya saat melakukan diskusi.

\section{Hasil Belajar Kompetensi Keterampilan}

Aspek yang diamati pada siklus I yaitu menyiapkan alat dan bahan, menuliskan hasil diskusi dan mempresentasikan hasil diskusi, sedangkan pada siklus II aspek yang diamati yaitu menyiapkan alat dan bahan, melakukan percobaan, menuliskan hasil percobaan dan mempresentaikan hasil percobaan.

Pada siklus I dan siklus II kompetensi keterampilan dari 36 orang siswa kelas $\mathrm{VII}_{8}$ SMPN 4 Kota Bengkulu sudah mencapai $100 \%$ yang artinya pada siklus I dan siklus II ini kompetensi keterampilan siswa sudah dikatakan tuntas karena telah mencapai ketuntasan klasikal yang telah ditetapkan sekolah sebesar $85 \%$.

\section{PENUTUP}

\section{Simpulan}

Berdasarkan hasil penelitian tindakan kelas VII 8 SMPN 4 Kota Bengkulu dengan menerapkan model Problem Based Learning pada materi pencemaran lingkungan, dapat disimpulkan bahwa Perbaikan pembelajaran dengan menerapkan model Problem Based Learning pada materi pencemaran lingkungan di kelas $\mathrm{VII}_{8}$ SMPN 4 Kota Bengkulu dapat meningkatkan aktivitas mengajar guru dan aktivitas belajar siswa. Selain itu Perbaikan pembelajaran dengan menerapkan model Problem Based Learning pada materi pencemaran lingkungan di kelas $\mathrm{VII}_{8}$ SMPN 4 Kota Bengkulu dapat meningkatkan hasil belajar siswa dari siklus I ke siklus II.

\section{Saran}

Diharapkan kepada guru mata pelajaran IPA-Biologi Kelas $\mathrm{VII}_{8}$ SMPN 4 
Kota Bengkulu dapat menggunakan model Problem Based Learning sebagai salah satu alternatif dalam pembelajaran untuk diterapkan pada pembelajaran IPA-Biologi sebagai salah satu upaya meningkatkan hasil belajar siswa. Selain itu Guru hendaknya memperhatikan waktu pada saat berlangsungnya proses pembelajaran agar tahap-tahap pembelajaran dapat terlaksana dengan baik.

\section{DAFTAR PUSTAKA}

Al-Tabany, Trianto Ibnu Badar. 2014. Mendesain Model Pembelajaran Inovatif Progresif dan Kontekstual. Jakarta : Kencana Prenada Media Group.

Arikunto, Suharsimi. 2010. Prosedur Penelitian : Suatu Pendekatan Praktik. (Edisi Revisi). Jakarta : Rineka Cipta

Arikunto, Suharsimi., Suhardjono dan Supardi. 2015. Penelitian Tindakan Kelas Edisi Revisi. Jakarta : Bumi Aksara

Dirman dan Juarsih, Cicih. 2014. Penilaian dan Evaluasi. Jakarta : PT. Rineka Cipta.

Gunantara. 2014. Penerapan Model Pembelajaran Problem Based Learning Untuk Meningkatkan Kemampuan Pemecahan Masalah Matematika Siswa KelasV.http://ejournal.undiksha.ac .id/index.php/JJPGSD/article/down load/Jurnal Skripsi (diakses pada tanggal 28 Januari 2017 pukul 23.00 WIB).

Harahap, M. A. dan Prastowo, P. 2014. Perbedaan Hasil Belajar Siswa Yang Diajar Menggunakan Model
Pembelajaran Project Based Learning Dengan Problem Based Learning Pada Materi Pencemaran Lingkungan.

http://digilib.unimed.ac.id/4828/1 /Fulltext.pdf (diakses tanggal 28 Januari 2017 pukul 20.30 WIB ).

Idrus, Ali. 2009. Manajemen Pendidikan Global. Jakarta: Gaung Persada.

Khalifah, N Umi. 2013. Penerapan Model Problem-Based Learning (PBM) Untuk Meningkatkan Aktivitas dan Hasil Belajar Biologi Siswa kelas $\mathrm{VIII}_{3}$ SMPN 21 Kota Bengkulu. Skripsi UNIB. Tidak Dipublikasi

Kosasih, E. 2014. Strategi Belajar dan Pembelajaran: Implementasi Kurikulum 2013. Bandung: Yrama Widya.

Panduan Penilaian Untuk Sekolah Menengah Pertama (SMP) Kementrian Pendidikan dan Kebudayaan Direktorat Pembinaan Sekolah Menengah Pertama Direktorat Jenderal Pendidikan Dasar Dan Menengah Tahun 2015.

Rusman. $2014 . \quad$ Model-Model Pembelajaran. Jakarta :Rajawali Pers.

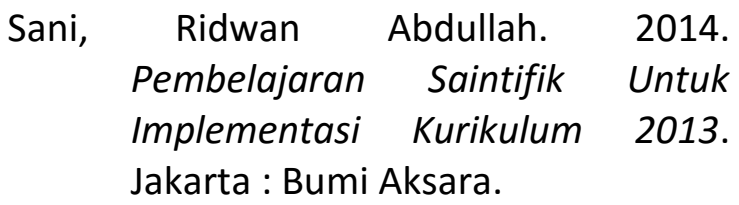

Suardani, Ni Nyoman. 2014. Pengaruh Model Pembelajaran Berbasis Masalah Terhadap Kemampuan Pemecahan Masalah dan Keterampilan Proses Sains Siswa. Jurnal Skripsi (diakses pada tanggal 17 Januari 2017 pukul 19.10 WIB). 
Sukardi. 2013. Metode Penelitian Pendidikan Tindakan Kelas, Implementasi dan Pengembangannya. Jakarta : Bumi Aksara.

Wijaya, I Wayan, dkk. 2015. Pengaruh Model Pembelajaran Berbasis Masalah Terhadap Hasil Belajar IPA Ditinjau Dari Minat Siswa Terhadap Pelajaran IPA Pada Siswa SD di Gugus IV Kecamatan
Manggis. Jurnal Skripsi (diakses pada tanggal 15 Januari 2017 pukul 23.00 WIB).

Zubaidah, Siti. 2014. Ilmu Pengetahuan Alam. Jakarta: Kementrian Pendidikan Dan Kebudayaan.

Zuriah, N. 2009. Metodologi Penelitian Sosial dan Pendidikan. Jakarta: PT Bumi

Aksara. 